\title{
Habitat, emosie en 'n eko-teologiese verstaan van menswees: In gesprek met Johan Buitendag
}

\begin{abstract}
Author:
Daniël P. Veldsman ${ }^{1}$

\section{Affiliation:}

${ }^{1}$ Department of Dogmatics and Christian Ethics, Faculty of Theology, University of

Pretoria, South Africa

\section{Correspondence to:}

Daniël Veldsman

Email:

danie.veldsman@up.ac.za

Postal address:

Private Bag X20, Hatfield

0028, Pretoria, South Africa

Dates:

Received: 24 Mar. 2014

Accepted: 24 Apr. 2014

Published: 05 Sept. 2014

How to cite this article:

Veldsman, D.P., 2014,

'Habitat, emosie en 'n

eko-teologiese verstaan

van menswees: In gesprek

met Johan Buitendag',

HTS Teologiese Studies/

Theological Studies 70(1),

Art. \#2668, 9 pages. http://

dx.doi.org/10.4102/hts.

v70i1. 2668
\end{abstract}

\section{Copyright:}

(C) 2014. The Authors.

Licensee: AOSIS

OpenJournals. This work

is licensed under the

Creative Commons

Attribution License.

\section{Read online:}

Habitat, emotion and an eco-theological understanding of humanity: In conversation with Johan Buitendag. The question on what his viewpoint of an eco-theological understanding of life entails is firstly posed in conversation with the South African systematic theologian Johan Buitendag. His stand point, in which he argues for the constitutive significance of habitat against the background of the philosophical, biological and theological contours of descriptions of what life is, is set forth. He suggests that human life should be described with regard to habitat in its constitutive significance and subsequently in regard to a value system, and concludes that human life as homo religiosus must be understood from an eco-theological viewpoint as ontologically extended ('ontologies uitgebreid'). His eco-theological viewpoint is secondly taken up in an explication of the sense making of human life by humans, determined and shaped by their biological roots in their habitat. Lastly the affective-cognitive dimension of being human with specific emphasis on affectivity is expounded as representing the embodiment of the logic of survival of personhood in their habitat.

\section{Inleiding}

In die Suid-Afrikaanse samelewing ${ }^{1}$ is daar ' $n$ klein aantal teoloë, natuurwetenskaplikes, filosowe en ander akademici, groepe en belangstellende individue vir wie die wetenskap-teologie gesprek ${ }^{2}$ belangrik is; belangrik om weliswaar heel uiteenlopende redes waarvan ek hier net'n paar noem. ${ }^{3}$ Vir sommige belangrik bloot omdat hulle baie nuuskierige en weetgierige mense is. Dit maak die lewe baie interessant. Vir ander weer belangrik omdat die geloofwaardigheid van teologiese nadenke vir hulle in hierdie gesprek op die spel staan en daarom moet hierdie twee mees dominante kulturele diskoerse (teologie en wetenskap) van ons tyd mekaar ernstig opneem (Van Huyssteen). Dis waardevol en verantwoordelik, lewensbepalend en lewensveranderend. Vir sommige ander weer is ons werklikheid een werklikheid en moet ons kennis van hierdie een werklikheid geïntegreer wees. Die gesprek maak vir hulle kreatief-interpretatiewe lewensmoontlikhede van hierdie een werklikheid oop. Vir ander weer verdiep en verbreed dit net eenvoudig hulle verwondering oor die skepping, oor lewe, menswees en oor die God wie bely word as skepper van hemel en aarde. Dit bring onder andere mee respek vir alle lewe, erkenning van menswaardigheid en diep ontsag vir die onpeilbare grootsheid van God en van die kosmos. Die Britse Anglikaanse priester wat vroeër 'n fisikus was, John Polkinghorne (2006) stel dit soos volg:

Those who are imbued with a thirst for understanding through and through - a desire that is extremely natural to the scientist - will find that this thirst will not be quenched by self-limited science alone.

1.Omdat hierdie artikel oor 'n Suid-Afrikaanse teoloog handel verwys ek dan spesifiek na hierdie konteks. My stelling (en afleidinge ten opsigte van die groter Suid-Afrikaanse konteks) berus onder andere op die werk van die Suid-Afrikaanse teoloog Peet van Dyk (2013) The Bible and evolution: Opinions amongst southern African clergy and theologians from the Reformed church tradition. Die situasie elders in ander wêrelddele verskil baie. So sou die situasie in Amerika en Europa moeilik vergelyk kon word met die situasie in situasie elders in ander wêrelddele verskil baie. So sou die situasie in Amerika en Europa moeilik vergelyk kon word met die situasie in byvoorbeeld die Asiatiese of Latyns-Amerikaanse lande. Sien oor laasgenoemde - om slegs een voorbeeld te noem - veral die bydraes van Anees (oor Islam), Subbarayappa (oor Hindoïsme), Thuan (oor Buddisme) en Kim (oor Asiatiese religieuse tradisies) in Watts en Dutton (2006) Why the science and religion dialogue matters. Die situasie in Suid-Afrika sou nogal in sekere opsigte met die in Amerika en Europa vergelyk kon word, en in ander opsigte weer met die in die Asiatiese en Latyns-Amerikaanse lande. Wat in die algemeen wel gestel sou kon word is dat die wetenskap-teologie gesprek nie die gewildste diskoers in meeste teologiese kontekste is nie. Die Amerikaanse teoloog Phil Hefner (2006) praat by geleentheid van 'n 'Third Community' as hy verwys na die teoloë wie betrokke is by die gesprek. Al is die gesprek vir teologiese nadenke met betrekking tot geloofwaardighed van groot belang, pas hierdie persone wie by die gesprek betrokke raak dikwels nie meer gemaklik in by sowel die teologiese as natuurwetenskaplike akademiese konteks nie.

2.Dit wat die Deense teoloog Niels Gregersen en die Suid-Afrikaanse teoloog Wentzel Van Huyssteen (1998) in hulle inleiding tot die boek oor ses eietydse modelle vir die wetenskap-teologie gesprek van reeds meer as sestien jaar gelede bespreek, is ongelukkig nog steeds nie vandag waar van hierdie gesprek in die Suid-Afrikaanse konteks nie. So stel hulle ten opsigte van hierdie gesprek in Amerika en Europa: 'Gone are the days in which any attempt to relate theology and science to one another could still possibly - and mistakenly - be seen as a rather esoteric, intellectualist exercise limited to a privilege few. 'Theology and science', as a very focused interdisciplinary venture, is indeed alive and well today on both sides of the Atlantic, as theologians, scientists, and philosophers are joining this complex cross-interdisciplinary conversations with its ever-new challenges and configurations. It seems that this ancient and enduring dialogue cross-interdisciplinary conversations with its ever-new challenges and configurations. It seems that this ancient and enduring dialogue has managed to successfully transform itself, in our present Western culture, into a sustained and dynamic contemporary discourse with its own prevailing identity for our time' (Gregersen \& Van Huyssteen 1998:1). Sien egter hulle goeie kort uiteensetting van die historiese
ontwikkeling in Amerika en Europa van hierdie gesprek (vgl. Gregersen \& Van Huyssteen 1998:1-11).

3.Dit is makliker om enkele internasionale en nasionale voorbeelde willekeurig saam te noem ten opsigte van die hieropvolgende uiteensetting van belangrike beklemtoninge in die wetenskap-teologie-gesprek. Die Amerikaanse filosoof Michael Ruse, wat homself 'n behoudende ateïs noem, verteenwoordig vir my die beste voorbeeld van 'weetgierigheid en nuuskierigheid'. Die Suid-Afrikaanse teoloë Wentzel van Huyssteen en Cornel du Toit sou ek wou noem as voorbeelde van die eis van 'geloofwaardigheid'. Die Deense teoloog Niels Gregersen en die Suid-Afrikaanse teoloog Klaus Nürnberger as voorbeelde van die beklemtoning van die 'werklikheid as een werklikheid' (so egter ook Van Huyssteen). Die Britse teoloë John Polkinghorne, Christopher Southgate en Celia Deane-Drummond, die Suid-Afrikaanse wiskundige George Ellis en die teoloog Ernst Conradie as voorbeelde van 'verwondering' en met gepaardgaande respek vir alle lewe en erkenning van menswaardigheid. So ook die Amerikaanse teoloë Ted Peters en Johan Haught. 
Religious insights offer us the prospect of finding a deeper level of understanding than that which we can get from scientific explanation on its own. That is why 'science and religion' matters. Combining these two great human encounters with reality offers the prospect of a more profound understanding than either could offer by itself. (bl. 29)

Gesamentlik bied hierdie gesprek vir ons as gespreksgenote meer om ons dors na 'n dieper vlak van kennis te les. Hieroor kan ons met Polkinghorne gerus saamstem. En dan voeg die Suid-Afrikaanse wiskundige George Ellis (2006) die volgende kwalifiserende woorde hierby:

... [T] he science and religion debate can be important in emphasizing the full dimension of humanity, and in particular the crucial role of value systems that cannot be derived from science alone. Thus, apart from its role in deepening the understanding of religious faiths in important ways, it can be an important integrative factor helping all humanity in the way we see ourselves and the universe in which we live, affecting our quality of life in a crucial way. It helps us be fully human. (bl. 5)

Meer omvattend kan dit nie gestel word nie: les ons dors na 'n dieper vlak van kennis sê Polkinghorne (2006). En: help ons om uit te kom by die volheid van menswees sê Ellis (2006). Of kort daar dalk nog iets in hierdie goeie omskrywinge? Ek dink so. Hierna kom ek weer terug. Net 'n laaste opmerking oor die gespreksgenote: Natuurlik - en dit het nog nie ter sprake gekom nie - is daar ook nog diegene wat geen erg hoegenaamd aan hierdie gesprek het nie en dit óf openlik afwys, óf ignoreer, óf doelbewus as onsin beveg, óf slegs op hulle eie voorwaardelike terme wil voer. Baie van hulle wat dit teenstaan het blykbaar hemelse kopiereg op alle kennis. ${ }^{4}$ Maar in hulle stel ek by hierdie een geleentheid nie belang nie. ${ }^{5}$

In hierdie artikel wil ek met waardering in gesprek tree met die Suid-Afrikaanse sistematiese teoloog Johan Buitendag vir wie die wetenskap-teologie gesprek uiters belangrik is en om hierdie rede die fokus van sy teologiese nadenke is. In hierdie artikel wat aan hom opgedra is, gaan ek in besonder kyk na sy eko-teologiese verstaan van menslike lewe soos spesifiek verwoord in sy onlangse bydrae 'Die noodsaaklikheid van habitat in ons definisie van menswees: Op soek na 'n ekoteologiese verstaan van menslike lewe' (Buitendag 2012). 6 Ek gaan in die eerste plek kyk waarom hy meen dat dit belangrik is en wat hiermee bedoel word. Daarop volg 'n kort uiteensetting van sy besondere konstruktiewe bydrae hieroor met spesifieke vooropstelling van die konsep habitat en laastens volg 'n uitbreiding op hierdie uiteensetting van habitat in 'n bespreking van dit wat ek noem die menslike meer van die habitat, dit is, die sinstigtende (interpretatiewe)

4.Met hemelse kopiereg op kennis bedoel ek religieuse standpuntinnames wat meen dat hulle oor 'die' openbaring beskik van die Bybel as wetenskaplike handboek waarvolgens hulle sonder enige kritiese verantwoording hulle standpunte mag voorhou oor die voorhande werklikheid as synde die (wetenskaplike) waarheid.

5.Sien hieroor Veldsman (2012) waarin voorbeelde van standpunte bespreek word wat die wetenskap-teologie gesprek teenstaan.

6. Hierdie is die mees resente wetenskap-teologie gespreksbydrae van Buitendag en verteenwoordig as eko-hermeneuties-teologiese standpunt oor menswees na my oordeel sy besondere bydrae wat hy tot die gesprek wil maak. Hierdie artikel is ' verwerking van sy voordrag wat by die European Society for Studies in Science and Theology (ESSSAT) in Tartu, Estonia op 25 April 2012 gelewer is. handeling van die mens met spesifieke toespitsing op die affektief-kognitiewe dimensie van menswees.

\section{Buitendag en habitat}

My waardering om in gesprek te tree met Buitendag hou veral verband met die wyse waarop hy die wetenskapteologie gesprek aanpak. Veral die drie vernaamste clichés wat Polkinghorne en Welker (2000) identifiseer wat volgens hulle 'n konstruktiewe gesprek tussen teologie en wetenskap bemoeilik, maak nie deel uit van sy aanpak nie, naamlik:

Theology deals with realities unseen, science deals with visible reality. Theology deals with feelings, science deals with facts. Theology deals - at best - with personal certainty, science deals with objective truth and so on. (bl. 3)

In sy aanpak word al drie hierdie clichés eksplisiet of implisiet aangespreek. So byvoorbeeld ten opsigte van die onvanpaste oortuiging dat die natuurwetenskappe werk met die sigbare werklikheid en teologiese nadenke met onsigbare werklikheid, pleit Buitendag (2012:1) vir 'n teologiese verstaan van menswees waarin ons erns sal maak met die biologiese wortels van menswees. Ook erns sal maak met die konstituerende betekenis van die omgewing (habitat) vir lewe. Beslis 'n teologiese aanpak wat erns maak met die sigbare werklikheid saam met die natuurwetenskappe. En hierby sou ek nog wou byvoeg: Sowel die natuurwetenskappe as teologiese nadenke bemoei hulle ook met onsigbare werklikhede. Net soos wat die sien van 'n atoom - vanuit 'n epistemologiese perspektief - slegs teoreties moontlik is, net so is die 'sien' van God alleen in getuienis - vanuit 'n epistemologiese perspektief - moontlik. Of dalk is die voorbeeld wat Buitendag (2012:2) self bespreek van die menslike embrio in die kliniese Petribakkie hier net so van pas met die ontwykende vraag - vir sowel die natuurwetenskaplike as vir die teoloog - of ons hier reeds met' $n$ mens te make het of nie? Dieselfde geld ten opsigte van die ander twee onvanpaste oortuiginge wat Polkinghorne en Welker (2000) benoem, naamlik dat dit in wetenskaplike nadenke alleen oor feite en objektiewe waarheid gaan en in teologiese nadenke - so word onvanpas beweer - net oor gevoelens en persoonlike sekerheid. Duidelik stel Buitendag (2012:2) dat die uitdaging vir teologiese nadenke is om interdissiplinêr en inklusief te dink. Beide hierdie beklemtonings van Buitendag dwing teologiese nadenke verby enige vorme van immuniseringsdenke wat byvoorbeeld persoonlike sekerheid of gevoelens voorop sou wou stel sonder enige eis tot verantwoording. Hier is ook van argumentatiewe belang die konstituerende betekenis van die omgewing (of soos hy dit stel: habitat of biotoop) vir alle bestaan en die aandrang op die ontginning van die aksiologiese dieptestruktuur ${ }^{7}$ van die natuur (vgl. Buitendag 2012:4, 7). Ek dink dat sy benaderingswyse omskrywe en saamgevat sou kon word met die woorde van die SuidAfrikaanse sistematiese teoloog Klaus Nürnberger wat dit pertinent stel: Die beste wetenskaplike insigte en die beste teologiese insigte moet saam bedink word (Nürnberger

7.Die woord aksiologie kom van twee Griekse woorde, naamlik axia (waarde) + logos (studie). Aksiologie is die studie van waardes. 
2013:stofomslag). In sy nuutste boek Informed by science, Involved by Christ (Nürnberger 2013) stel hy dit samevattend soos volg:

Do faith and science compete with each other? Do they exclude each other? Can we dispense with either faith or science? By no means! Science and faith complement each other! We need both information and commitment - and we need them badly! ... 'Best science' consists of the best theories about reality available at present. As such, it can update, enrich and empower the world view of faith. 'Best faith' is capable of providing human life, including that of the scientist, with grounding direction and motivation. Science and faith are indispensible human pursuits. (bl. 16)

Dit wil Buitendag ook: Beste wetenskaplike insigte en beste teologiese insigte hoort saam. Met hierdie drie onvanpaste oortuiginge (clichés) waarop Polkinghorne en Welker (2000) ons bedag maak agter die argumentatiewe rug en die formele aanduiding van Buitendag se benaderingswyse tot die wetenskap-teologie gesprek, is die vraag vervolgens na die inhoudelike verstaan van sy standpunt van die ekoteologiese verstaan van menslike lewe.

Sy oogmerk is om by 'n teologiese verantwoordelike konsep van lewe uit te kom aangesien hy meen dat die biokulturele paradigma $^{8}$ aangevul moet word met 'n verruimde ekososiologiese paradigma van menswees. Hy neem sy uitgangspunt by die oortuiging dat lewe nie volledig slegs in terme van liggaam, óf gees óf siel of selfs persoonwees beskrywe kan word nie. Indien dit in definisies omskrywe word, voer hy aan, moet twee uiterstes gebalanseer word te wete beskrywinge van dinge wat as lewensloos geag word maar wel binne die beskrywing van lewe pas, en dinge wat as lewend geag word, maar nie binne die beskrywing pas nie. ${ }^{9}$ Gegewe hierdie moeilike toedrag van sake, meen Buitendag om eerder by'n Bybels-verantwoorde verstaan van lewe uit te kom en nie soseer'n definisie nie. Daarom sy keuse vir habitat of biotoop ${ }^{10}$ wat beslis - in verwysing na die Deense teoloog Niels Gregersen - deel moet wees van ons antropologie (vgl. Buitendag 2012:1). Vir 'n teologiese antropologie pleit hy nie alleen vir die herontdekking van die biologiese wortels van die menslike persoon nie, maar 'ook die erkenning van die verweefde omgewingseffek wat die wisselwerking tussen die genotipe en die fenotipe op die menslike persoon

8 .Eers in die laaste gedeelte van sy argument motiveer Buitendag (2012:7) sy aanvulling van die biokulturele paradigma wanneer hy stel dat die wisselwerking
binne en met die habitat - wat op sy beurt weer deel van 'n grotere ekostelsel uitmaak - ontsnap die gesigveld van die term.
uitman

9.Buitendag (vgl. 2012:1) se afleiding hieruit dat Potter dalk 'n punt beet sou hê wanneer hy na die moontlikheid verwys dat lewe bloot 'man's perception of matter' is en dus geheel en al subjektief en per implikasie ondefinieerbaar is, is na my oordee nie houdbaar nie. Hier het ek ingedagte die baie bekende godsdienspsigoloog Dr James Leuba (1867-1946) se eksperiment baie jare gelede met sy studente. Leuba het meer as vyftig definisies van sy studente as terugvoering gekry oor sy versoek om religie te definieer. Die studente het as gevolg van hierdie omvangryke uiteenlopende en verskillende definisies beweer dat religie nie gedefinieer kan word nie. Hierop het Leuba met wysheid - waarmee ek identifiseer - geantwoord dat die implikasie is eerder dat die woord religie op meer as vyftig verskillende wyses omskrywe kan word waarvan sekere beskrywinge meer suksesvol is as ander. Dit beteken dus nie dat religie nie definieerbaar is nie. Ek dink ook nogal so oor die omskrywinge van lewe.

10.Die woord biotoop kom van die Griekse woorde bios [lewe] + topos [plek] en word gewoonlik as sinoniem van habitat gebruik. Die algemene betekenis is die van 'n uniforme omgewing wat lewe moontlik mak. Dit word egter somtyds in sekere

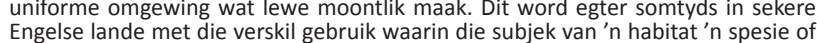
Engelse lande met die verskil gebruik waarin die subjek van 'n habitat 'n sp
bevolking is, terwyl 'n biologiese gemeenskap die subjek van 'n biotoop is. het' (Buitendag 2012:1). Konkreet kom sy vraagstelling teen die agtergrond van sy kenteoretiese voorveronderstellinge neer op die vraag: Wat sien ons as lewe en waarop begrond ons dit (vgl. Buitendag 2012:2)?

Om hierdie vraag te beantwoord moet ons gegewe die aantal gespreksgenote ${ }^{11}$ ons vertrekpunt neem by die ontwikkeling van die begrip lewe sodat ons vanaf die filosofies-historiese kontoere na die biologiese kontoere beweeg om uiteindelik by die teologiese kontoere uit te kom (vgl. Buitendag 2012:2-3). Eersgenoemde, naamlik die:

- Filosofiese kontoere is noodsaaklik op grond van die begripsontwikkeling wat plaasgevind het vanaf 'n atomistiese (of animisties) verstaan van lewe na 'n meer dualistiese of meganistiese verstaan tot uiteindelik die verstaan van lewe as 'n proses of organisasie. Buitendag (2012:2-3) benoem Aristoteles (wat in hierdie kosmos wou leef en dink) as voorbeeld van 'n atomistiese verstaan en wys op sy belangrike onderskeid tussen potensialiteit en aktualiteit wat hy gemaak het. Descartes word as voorbeeld genoem van die meer dualistiese verstaan. Hy het van die beginsel van volstrekte twyfel gebruik gemaak om alle skynsekerhede van sintuiglike waarneming te ontmasker en die standpunt voorgehou dat die menslike rede alleen tot die kern van waarheid kon deurdring. Kant word as voorbeeld van die verstaan van lewe as proses geneem. Vir hom kon niks sonder 'n doel bestaan nie en daarom is biologie alleen in terme van 'n instrinsieke teleologie beskrywe.

- In sy bespreking van die biologiese kontoere gaan dit vir Buitendag (2012:3-5) teen die agtergrond van Darwin se uiteensetting van die afkoms van lewe, oor die interaksie van lewe met die omgewing, die wisselwerking tussen organisme en omgewing, en veral die konstitutiewe betekenis van die omgewing (as habitat of biotoop) vir alle bestaan (soos in molekulêre biologie) en uiteindelik die allesbepalende verhouding tussen die genotipe en fenotipe. Veral laasgenoemde - wat as 'fenotipiese plastisiteit' uitgewerk word (vgl. Buitendag 2012:4) - vereis 'n ekstra beskrywende woord. Dit is die organisme se vermoë om sy fenotipe aan te pas na gelang van verandering in sy omgewing. En vanuit hierdie aanpassing, blyk dat alle eienskappe van spesies sowel genetiese as omgewingsfaktore veronderstel (vgl. Buitendag 2012:5). Buitendag (2012:5) sluit sy bespreking van die biologiese kontoere af met 'n bespreking van die terme waarmee die omgewing van lewe en die wisselwerking met die omgewing omskrywe kan word. So verwys hy na ekosisteme (d.i. lewende organismes in wisselwerking met hulle omgewing), ekologie (d.i. studie van lewende organismes en hulle habitat asook die wedersydse wisselwerking daartussen), biotoop (d.i. die omgewing wat organismes huisves) en ekostelsel (d.i. die eenheid wat tussen die biotoop en organisme bestaan). Die punt wat hy hier wil uitlig en

11.Buitendag (2012:2) wys daarop dat klassieke biologie lank nie meer die enigste vakgebied is wat oor lewe nadink nie. In die afgelope dekades het daar volgens hom veral drie navorsingsvelde ontwikkel as dominate gespreksgenote oor die debat van lewe te wete eksobiologie, artifisiële lewe en oorsprong van lewe. 
beklemtoon is die wyse waarop habitat uiteindelik 'n konstituerende deel uitmaak van antropologie.

- Die uiteensetting van die teologiese kontoere begin met 'n verwysing na die beskuldiging van Lynn White, naamlik dat die Judaïsties-Christelike godsdienste met hulle dogmas oor die skepping (waarin die mens as heer en meester verkondig word), medeaanspreeklik gehou kan word vir die ekologiese krisis. En omdat die oorsaak van die probleem hier begin, moet die oplossing ook hier gesoek word. Dit word verwoord deur White in die versugting na die opkoms van 'n nuwe godsdiens (vgl. Buitendag 2012:6) wat inderdaad sedertdien op verskeie terreine impulse gevind het. Impulse nie alleen uit etiese kontekste nie, maar ook nou met feministies-ekologiese stemme, Bybelwetenskaplikes met 'n ekologiese hermeneutiek en uiteindelik 'n werklike groen godsdiens met die verskyning van Taylor se Dark green religion (2010) (aangehaal in Buitendag 2012:6). Die duidelike punt wat vanuit hierdie ontwikkelinge geneem kan word, is die diepersnydende ekologiese hermeneutiek waarin die klassieke interpretasie van Bybelgedeeltes gedekonstrueer word. Nuwe belangrike teologiese beklemtoninge wat hieruit voortspruit is onder andere die Sabbat en God as hoogtepunt van die skepping en nie dag ses en die mens nie (vgl. Buitendag 2012:6).

Hoe nou verder met hierdie eko-hermeneutiek en ekoteologiese verstaan van menswees indien ons hierdie drie kontoere soos voorafgaande uiteengesit, verdiskonteer?

Buitendag (2012:6-7) ondersteun omskrywinge van lewe waarin die klem op die eko-relasionele dimensie val, dit wil sê, omskrywinge wat vra na die omgewing (habitat) van lewe. Alhoewel hy sterk aansluiting vind by die Australiaans-Amerikaanse teoloog Wesley Wildman se mensbeskrywing as 'a walking, feeling, thinking superorganism, an entire mobile ecology of organisms' (Wildman aangehaal in Buitendag 2012:7), voer hy aan dat ook hierdie omskrywing nog steeds afbreuk doen aan die mens se partisiperende deelname aan die groter habitat. Die ekologiese bedding word nie toerreikend verreken nie. Om dieselfde rede wys hy die biokulturele paradigma af. ${ }^{12}$ In hierdie argumentatiewe konteks voer Buitendag aan dat hy vir 'n herwaardering vra van 'n Christelike antropologie wat met 'n groen hermeneutiek die Bybel benader (Buitendag 2012:7). Vir hierdie herwaardering in sy groen hermeneutiek is habitat sowel as 'n waardesisteem belangrik en stel Buitendag (2007):

So belangrik as wat ' $n$ gunstige habitat of biotoop vir die mens is om te oorleef, gedy en te evolueer, so belangrik is dit ook om

12.In hierdie 2012-afwysing van die biokulturele paradigma is 'n baie duidelike verskuiwing in Buitendag se eie beklemtoning te bespeur. Nou staan die habitat voorop en die biokulturele klem van 2009 word gekwalifiseerd op sy plek gesit. In sy eie woorde: 'A critical-realistic approach to reality opens up the possibility for a Christian natural theology to develop, in terms of which members of the faithful can both interact from within a bio-cultural niche, as well as experience the coram can both interact from within a bio-cultural niche, as well as experience the coram Deo, as well as in terms of which love can be hypostasised. A theology of nature, therefore, amounts to the human perception of nature, as it is shaped through a specific lens. Due to the involvement of the total human being, such a lens is consciously and subconsciously shaped within a bio-cultural framework, in which human experience and imagination play a significant role. A member of the faithfu hears the voice of the Caller in a manner that accords with Scriptural norms, and reacts by striving to lead a life of all encompassing love' (Buitendag 2009:9). 'n bepaalde waardesisteem vir die verstaan van menswees te konsipieer. (bl. 7)

Vir Buitendag (2012:7) vind hierdie waardesisteem - wat saamgaan met die habitat - uitdrukking op grond van religieuse simbole en daarom formuleer hy as slotsom dat 'n 'eko-sosiologiese verstaan van homo religiosus impliseer dus om menslike lewe as ontologies uitgebreid te verstaan.' $\mathrm{Na}$ hierdie slotsom wil ek ten slotte kyk en die vraag stel na hierdie 'verstaanshandeling' van die mens (dit is die partisiperende deelname) en dit spesifiek tipeer as 'n besondere affektief-kognitiewe handeling wat menswees ten diepste karakteriseer.

\section{Die 'affektief-kognitiewe singewende meer' van die mense in hulle habitat}

Sonder enige twyfel meen ek dat die besondere beklemtoning van Buitendag op die konstituerende betekenis van habitat erken en voller uitgewerk moet word. Geen verantwoordelike antropologie kan sinvol daarsonder nie. Hier sou ek egter een spesifieke dimensie van partisiperende menswees in sy of haar omgewing wou uitlig. Wou uitlig omdat ek meen dat geen beklemtoning van die konstituerende betekenis van habitat sonder hierdie interpretatiewe inkleding kan geskied nie. Hier verwys ek na die sinstigtende of singewende menslike handeling (sensemaking) in hulle habitat vanuit ons biologiese bepaaldheid. Die punt waarby ek uiteindelik wil uitkom is die inhoudelike nadere karakterisering van 'oorlewing' in hierdie omgewing van 'meer as net fisiese' lewe. Ek meen dit verteenwoordig die eksistensiële (persoonsmatige) binnekant van Buitendag (2012:7) se konklusie waarin hy stel dat die 'eko-sosiologiese verstaan van homo religiosus impliseer dus om menslike lewe as ontologies uitgebreid te verstaan.' Ek wil in aansluiting by die neurobioloë LeDoux en Damasio en die godsdiensfilosoof Stoker op die besondere affektief-kognitiewe dimensie van menswees fokus. Spesifiek wil ek affektiwiteit (wat emosie, gevoel en gemoed insluit) uitsonder en motiveer as die beliggaaming van die logika van oorlewing in die lewensomgewing (habitat). Dalk eenvoudiger gestel: As partisiperende mense oorleef ons in (en maak dus sin van) ons omgewing nie in die eerste plek op grond van sterkte, of selfs op grond van aanpasbaarheid nie, maar veral op grond van ons affektief-kognitiewe samestelling, in besonder ons affektiewe vermoë tot empatiese mee- en inlewing. ${ }^{13}$

Ten einde ons rol van 'partisipasie' as sinstigtende handeling in ons spesifieke habitat duideliker uiteen te sit, wil ek my vertrekpunt neem by 'n opmerking van die Britse filosoofteoloog Conor Cunningham. In sy Darwin's Pious Idea in verwysing na George Wald wat in die inleiding tot The Fitness of the Environment van Lawrence Hendersen (1958) geskrywe het: 'A physicist is the atom's way of knowing about atoms' (Cunningham 2010:159). Hierdie opmerking wil ek verwerk

13.Met die woord 'empatiese meelewing' wil ek die begrippe 'compassion', 'kindness', 'empathy' almal insluit. Dit gaan oor die emotiewe aanduiding van dit wat as altruisme omskrywe word. 
vir my doeleindes tot die volgende: menswees is die wyse waarop lewe lewe ken. Daarsonder is daar niks. Absoluut niks. Nee eers ' $n$ habitat om van te praat nie. In erkenning van die konstituerende betekenis van die habitat meen ek moet ons terselfdertyd dus ook besin oor die singewende meer. Soos die Suid-Afrikaanse sistematiese teoloog Cornel $\mathrm{du}$ Toit (2012:54) dit by geleentheid stel: 'There is a need to read "more than" into the story.' Hierdie 'meer as' omskrywe hy as volg:

The world we see is more than the physical reality around us. It is a world (cultural environment) constructed by human interpretation, co-determined by our specific culture, religion and society. This world is value-laden. (Du Toit 2007a:15)

Nog duideliker stel hy (Du Toit 2007a) dan verder:

The meaning of human life crystallises in the values people hold, the communities they make and the belief systems they live by. The emphasis on human beings as moral beings restores their place and dignity in the universe. From a human point of view the physical universe on its own is incomplete. It cannot explain itself. Human beings are built into the scheme of things in a very basic way. (bl. 16)

Inderdaad is die singewende mens ('a world constructed by human interpretation') en die aksiologiese dieptestruktuur ('this world is value-laden'/'the belief systems they live by') op ' $n$ baie basiese wyse in die lewenskema van dinge ingebou. Die fisiese universum, en dus ook ons habitat is op sy eie genome onvolledig. ${ }^{14}$ Onvolledig selfs met inagneming van die konstituerende betekenis van die habitat en in erkenning van ons fenotipiese plastisiteit (Buitendag 2012:4). Dit kort 'interpretatiewe aanvulling'. Maar dit beteken egter nie dat die interpretatiewe aanvulling ten aansien van die onvolledigheid nou volledig as kognitief verstaan moet word nie. Dalk duideliker gestel, op reduksionistiese wyse in navolging van Descartes - tot die rede vereng moet word nie. Sou verenging impliseer dat ons sinstigtende handeling in ons habitat alleen maar ' $n$ kognitiewe handeling sou wees? Anders gesê, dat ons alleen maar ter wille van ons oorlewing as mense en die inrigting van ons wêreld aangewese is op ons rede? Tereg sou ons hierteenoor kon protesteer en die Nederlandse filosoof Gijs Dingemans in sy onlangse boek Het brein geeft te denken (2012) help ons hiermee. Op duidelike en oortuigende wyse kritiseer hy die populêre en invloedryke rasionalisties-antroposentriese perspektiewe wat sou wou voorgee dat 'wij zijn ons brein' (Dingemans 2012:8). Reeds drie jaar voor Dingemans het die Duitse neurowetenskaplike Thomas Fuchs (2009) presies dieselfde kritiek verwoord in sy 'beliggaamde of enaktiewe kognitiewe wetenskaplike benadering.' Sterk afwysend - net soos Dingemans reageer hy op sy kollegas wie se antropologiese beskouinge neergekom het op '[y]ou are but a pack of neurons' of '[y]ou are your brain' (Fuchs 2009:3). Hy noem dit sowel 'n kategorie

14. Hierdie onvolledigheid as voortgaande taak omskrywe die Nederlandse filosoo Bas van Fraassen (2002: xvii) as volg: 'In every century again we must interpret ourselves to ourselves. We do not come into our century with a tabula rasa. We must interpret what we find ourselves to be, with an eye to what we have been and to what we could be and can be. This is the perennial, ever recurning task, ever new. What we find include both science and religion, the secular and the spiritual, and what we transform in our reinterpretation includes the contrast and boundaries between these two.' flater as ' $n$ biologies onvanpaste oortuiging. As mense in ons singewende omgewing met ons leefwêrelde, is ons meer. Meer as ons fisiese leefwêreld. Veel meer as net ons breine en ons rasionele omgang met hierdie leefwêreld. Fuchs (2009) se besondere bydrae kan saamgevat word in sy verduidelikende woorde waarin die konstituerende betekenis van - om Buitendag se woordkeuse hier op te neem - die habitat onder andere ook duidelik beklemtoon word:

Present cognitive neuroscience regards the mind as somehow localized in, caused by, or identifiable with the brain. However, this short-circuit between mind and brain leads into a conceptual and methodological impasse, for it misses the essentially embodied, relational and biographical character of the human mind. To find our way out of this impasse, we have to overcome the dualism of mind and brain by taking into account the phenomenon of life, including the organism, the lived body and the life world in which both mind and brain are embedded. This leads to my thesis: The individual mind is not confined within the head, but extends throughout the living body and includes the world beyond the membrane of the organism, especially the interpersonal world of self and other; this is also the world in which mind and brain are essentially formed. (Fuchs 2009:3)

Ek sou hierdie voorafgaande 'meer' van Du Toit, die kritiek op die redusering van ons omgang met ons leefwêreld (Dingemans, Fuchs) tot net ons brein of rede, en die besondere beklemtoning van die konstituerende betekenis van ons habitat (Buitendag; Fuchs in sy beliggaamde kognitiewe benadering) van ons menswees aan die hand van die Engelse idiomatiese uitdrukking wou formuleer as my werkstese, naamlik 'home is where your heart is'. Of anders gesê, habitat kan affektief-eksistensieel uitgebrei word as ons 'verlange na geborgenheid' of 'versugting na behoort' ${ }^{15}$ Hierby wil ek uiteindelik uitkom via 'n kort bespreking van die belang van affektiwiteit in ons lewens.

Vanuit ons biologiese bepaaldheid blyk ons affektiewe dimensie (wat ons emosies, gevoelens en gemoed insluit) van menswees. Op grond hiervan moet ons eerder praat van die affektief-kognitiewe dimensie van ons menswees en nie slegs van ons kognitiewe dimensie nie. Hierdie dimensie is nie alleen op 'n oortuigende wyse deur verskeie neurobioloë aangedui nie, maar veral die belang vir ons menslike oorlewing in ons habitat word blootgelê. Die twee persone wie se klassieke bydraes ek in hierdie verband sou wou uitsonder is die Amerikaanse neurowetenskaplike Joseph LeDoux in sy The emotional brain (1996) en die PortugeesAmerikaanse neurobioloog Antonio Damasio in sy The feeling of what happens (1999). Hulle navorsing oor die affektiewe dimensie van menswees vanuit ons biologiese bepaaldheid in ons leefwêrelde, het radikale nuwe evolusionêre insigte oor die rol van emosies in ons lewens ontsluit. Waarskynlik som die Switsers-Kanadese filosoof Ronald De Sousa (2013) dit die beste op wanneer hy oor emosies stel:

No aspect of our mental life is more important to the quality and meaning of our existence than emotions. They are what make life worth living, or sometimes ending. (bl. 1)

15.Met die tipering van affektief-eksistensieel bedoel ek eenvoudig dit wat na my oordeel die mees besondere karakteriserende kenmerk is van menslike lewe as menswees-in-die-wêreld-wees. 
Hier sal ek moet volstaan met enkele insigte van LeDoux en Damasio in die uitspel van 'what makes life worth living, or sometimes ending' met spesifieke verwysing na die kwaliteit en betekenis van menslike bestaan.

\section{Enkele sleutelopmerkinge van LeDoux en Damasio}

Vir LeDoux (1996:25) is emosielose kognitiwiteit 'ondenkbaar'. Hy stel:

$[M]$ inds without emotions are not really minds at all. They are souls on ice - cold lifeless creatures devoid of any desires, fears, sorrows, pains, or pleasures. (LeDoux 1996:25)

Oor die brein se evolusionêre ontwikkeling is LeDoux (1996) uitgesproke. Dit is:

... the most sophisticated machine imaginable, or unimaginable, yet it wasn't predesigned. It is the product of evolutionary tinkering, where lots of little changes over extremely long periods of time have accumulated. (bl. 104)

Wat vir my in hierdie konteks oor emosie van belang is, is die evolusionêre ontwikkeling van ons emosies waarvan baie 'exist as part of complex neural systems that evolved to enable us to survive' en is uiteindelik te verstane as 'n 'subjective experience, a passionate invasion of consciousness, a feeling'. (LeDoux 1996:267)

Hierop brei hy (LeDoux 1996) soos volg uit:

Conscious emotional feelings and conscious thoughts are in some sense very similar. They both involve the symbolic representation in working memory of subsymbolic processes carried out by systems that work unconsciously. The difference between them is not due to the system that does the consciousness part but instead is due to two other factors. One is that the emotional feelings and mere thoughts are generated by different subsymbolic systems. The other is that emotional feelings involve many more brain systems than thought. (bl. 299)

Emotiewe response is 'hard-wired into the brain's circuitry', maar die dinge wat ons emosioneel maak 'are learned through experience.' En hierdie leerproses ${ }^{16}$ gaan met 'waarderinge' (appraisals) ${ }^{17}$ gepaard wat in die amagdala geprosesseer word. Die punt is, emosies het ' $n$ kognitiewe element, is as kognitiewe element oor eeue heen evolusionêr gevorm. En, dit speel 'n kardinale rol in ons oorlewing in ons spesifieke habitat.

Damasio (1999) - ten spyte van baie ander uiteenlopende beklemtoninge in vergelyking met LeDoux (1996) - sluit

$16 . V a n u i t$ " $n$ wye spektrum van neurobiologiese metodes spits LeDoux (1996) sy navorsing toe op die amygdala, 'n klein area wat weggesteek lê in die tempora gedeelte van die brein. Vir LeDoux verteenwoordig dit die hart van die emotiewe sisteem. Dit prosesseer die emosionele betekenis van individuele stimuli sowel as komplekse situasies.

17.Die woord wat deur LeDoux (1996:282) geskep word vir die beskrywing van die aktiwiteit van die amygdale, naamlik 'waardering' (appraisal) moet nader aangedui word: Waardering ('as the comparison of an event to a person's goals and resources') is die 'process that cognitive researchers agree is the key to how particular emotions are produced in response to particular kinds of events.' Die baie interessante konsep wat LeDoux munt om die werking van waardering (appraisals) te verduidelik, is ' $n$ 'werksgeheue'. Hy verduidelik soos volg: 'I'm saying

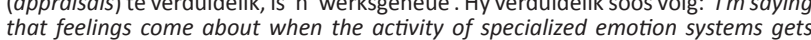
represented in the system that give rise to consciousness, and I'm using working
rition represented in the system that give rise to consciousness, and l'm using working
memory as a fairly widely accepted version of how the latter might come about' memory as a fairly
(LeDoux 1996:282). ten nouste by hom aan. Ook hy stel die sogenaamde verwyt van die irrasionaliteit van emosionaliteit voorop wat hy (Damasio 1999) beslissend wil afwys:

Throughout most of the twentieth century, emotion was not trusted in the laboratory. Emotion was too subjective, it was said. Emotion was too elusive and vague. Emotion was at the opposite end from reason, easily the finest human ability, and reason was presumed to be entirely independent from emotion. This was a perverse twist on the Romantic view of humanity. Romantics placed emotion in the body and reason in the brain. Twentieth-century science left out the body, moved emotion back into the brain, but relegated it to the lower neural strata associated with ancestors who no one worshiped. In the end, not only was emotion not rational, even studying it was probably not rational. (bl. 39)

Vir Damasio wat bewussyn ${ }^{18}$ eenvoudig maar treffend omskrywe as 'the feeling of what happens' gaan bewussyn, selfbewussyn en emosie onlosmaaklik saam. Meer spesifiek gesê, rasionaliteit en emosie gaan op so 'n operasionele wyse saam dat in die "feeling of what happens" as self-consciousness, emotion constitutes ... a support system without which the edifice of reason cannot operate properly' (Damasio 1999:42). En van die belang van bewussyn ${ }^{19}$ wat ingebed is in die groter raamwerk van lewe self, voer hy aan: '... [c]onsciousness has succeeded in evolution because it supports life most beautifully' (Damasio 1999:135).

Van belang hier is sy omskrywing en verstaan vanuit kliniese en anatomiese navorsing en bevindinge dat emosies ${ }^{20}-$ wat biologies bepaald en stereotipies is - omskrywe kan word as 'patterns of chemical and neural responses, the function of which is to assist the organism in maintaining life by prompting adaptive behaviours' (Damasio 1999:141). ${ }^{21}$ Emosies is die gevolg van die aktivering van 'n stel van sekere breinstrukture waarvan die meeste ook verantwoordelik is vir die monitering en regulering van liggaamstoestande rondom optimale fisiologiese waardes. Hierdie prosesse staan bekend as homeostasis of homeodinamika (vgl. Damasio 1999:141). Die breingedeeltes wat vir emosies verantwoordelik is, is die amagdala (die sentrum van die aktiveringsgebeure) en hipotalamus (die sentrum van die uitvoering). Die fisiologie van emosies kan nie maklik beskrywe word nie, omdat soveel strukture en terugvoeringsreaksies tegelykertyd

18.Sien Damasio (1999) se baie insiggewende bespreking van bewussyn en selfbewussyn, en hieruit die onderskeid van kernbewussyn (wat gemoeid is met die hier en nou) en uitgebreide bewussyn (wat onder andere die autobiografiese geheue en persepsie van tyd insluit).

19.Slegs enkele aangrypende en omvattende omskrywinge van Damasio oor bewussyn kan hier aangedui word. So byvoorbeeld stel hy: "[T]he power of consciousness comes from the effective connection it establishes between the biological machinery of individual life regulation and the biological machinery of thought. That connection is the basis for the creation of an individual concern which permeates all aspects of thought processing, focuses on all problem-solving activities, and inspires the ensuing solutions. Consciousness is valuable because it centers knowledge on the life of an individual organism' (Damasio 1999:304). Teen hierdie agtergrond stel hy die diepgaande probleem van bewussyn in die metaforiese taal van die 'movie-in-the-brain' en die daaropvolgende beskrywing van die 'sense of the self'.

20.Die ses basiese primêre of universele emosies wat onderskei word is treurig en gelukkig wees, vrees, woede, veragting (disgust) en verras wees.

21.Twee verdere onderskeidinge is hier van belang te wete sekondêre en agtergrondemosies. Sekondêre of ook genoem sosiale emosies behels onder andere skaamte, jaloesie, skuld en trots. Agtergrondemosies behels onder andere kalmte, gespannendheid, moegheid, energiekheid ensovoorts. 
geaktiveer word. Om hierdie rede voer Damasio aan dat daar nie 'n eenvoudige liniêre proses is waarvolgens emosionaliteit beskrywe kan word nie. Dit skep oneindige probleme met die konseptualisering van vlakke en volgordes van prosessering. Tog onderskei Damasio (1999:279, 282 e.v., 291 e.v.) tussen 'n gevoel (feeling) en 'n emosie. Vir hom is 'n gevoel 'a mental representation of the state of the organism's body, the perception of body state' terwyl 'n emosie is vir hom die '... reaction to a stimulus and the associated behaviour (eg. a facial expression).' Op hierdie wyse omskrywe hy gevoel as die erkenning dat iets gebeur ('an event is taking place'), terwyl emosie weer die sigbare effek daarvan is. Daarom sê hy dat emosies eerder met ons (biologiese) lyflikheid te make het en ons gevoelens met bewustelikheid ('emotions are bodily things, while feelings are mental things'). Omdat emosies die 'bodily things' wat outomatiese reaksies is en geen denke aldus Damasio inhou, is hulle die fundamentele meganisme vir die regulering van lewe. Emosies gaan dus gevoel vooraf, en is die basis vir gevoelens. Evolusie het ons voorberei met 'n stoorkamer ('repertory') vol emosies waarvan ons gebruik maak in verskillende omstandighede. Die effek van 'n emosie is sowel een of ander liggaamsreaksie en die skep van 'n neurale kaart ('neural map'). Dit is die neurale kaart wat aanleiding gee tot die spesifieke gevoel. Die verhouding tussen hierdie neurale kaarte en gevoelens reflekteer hoe goed die liggaam doen ooreenkomstig die neurale kaart. Die neurale kaarte van liggaamstoestande is uiters nuttig in die bestuur van die liggaam. Maar veral belangrik is dat gevoelens ons toelaat om op 'n redelike wyse oor die oorsaak van 'n emosie te praat. Dit laat ons toe om die groter prentjie te sien en nie net meganies op 'n situasie te reageer nie. Daarom stel Damasio dat ' $n$ emosie deur die brein geregistreer word wanneer 'n stimulus herken word as bruikbaar vir oorlewing of goed of sleg onderskeidelik vir oorlewing of welwese ('well-being'). Net soos LeDoux praat Damasio (1999) ook hier van evaluering ('appraisals') wat plaasvind en veranderinge van liggaamstoestande (bv. toename in hartklop; sametrekking van spiere ens.) wat teweeggebring word. Die verandering in liggaamstoestande impliseer dat 'n neurale kaart verander in die brein en dat hierdie verandering die fisiese implementering is van die gevoel.

\section{Stoker en die affektief-kognitiewe dimensie van menswees}

In sy Is faith rational? (2006) argumenteer die Nederlandse godsdiensfilosoof Wessel Stoker ${ }^{22}$ op oortuigende wyse dat ten einde standpunte te weerlê wat emosionaliteit sonder meer afmaak as irrasioneel, moet ons standpunte oor emosie afwys wat emosies beskou as een of ander innerlike gevoel of sensasie wat slegs in 'n fisiologies-kousale verband met leefwêreld en of objek staan (vgl. Stoker 2006:166 e.v.). So is daar in hierdie onaanvaarbare standpunte geen onderskeid tussen byvoorbeeld die emosies van honger en van woede nie. Volgens so 'n verstaan van emosie, hou emosies geen verband met enige idee (d.i. kognitiewe inhoud) of oordeel (d.i. kognitiewe aktiwiteit) nie. Met Fuchs, LeDoux en Universiteit, Amsterdam, Nederland.
Damasio se voorafgaande neurowetenskaplike bydraes in gedagte, en met enkele hersienings in Stoker se filosofiesteologiese bydrae wil ek hierteenoor en uitbreidend daarop die volgende stel:

- Ons emosies en gevoelens is gewortel in ons biologiese herkoms en het oor eeue heen evolusionêr ontluikend ontwikkel (in die sin van 'emergence') vanuit die basiese instinkte van paring, beskerming van gebied, soeke na kos, oorlewing ensovoorts en het dus 'n (evolusionêre) kognitiewe kern.

- Emosies of gevoelens word nie-bewustelik en bewustelik gekommunikeer deur verskillende liggaamsisteme en subsisteme wat uit neurale netwerke en bloednetwerke bestaan.

- Ten minste drie komponente kan onderskei word in die standpunte oor emosies wat hulle uitgangspunt neem in ons biologiese herkoms. Eerstens die fisiologies en/of psigologiese bewussynsmoment ('state-of-the-mind component') van die persoon wat die emosie of gevoel ervaar; tweedens die objek van die emosie as komponent; en derdens die betrokke relevante rasionele redes vir die emosie as komponent. Daar is dus mentale of kognitiewe en fisiese komponente van emosies of gevoelens.

- Daar is egter meer ter sprake as net emosies in die begrip affektiwiteit. In navolging van die OostenrykNederlandse Stephan Strasser ${ }^{23}$ se Phenomenology of feeling (1977) praat Stoker (2006:179 e.v.) in sy uiteensetting van religieuse affektiwiteit van die gelaagdheid van affektiwiteit. Hiervolgens word onderskei tussen gemoed, emosies en gevoelens. Gemoed verteenwoordig die diepste, ongedifferensieerde laag van affektiwiteit. ${ }^{24}$

- Gemoed lê ons diepste aard van menswees bloot, dit is, ons 'geworpenheid in bestaan' (Stoker 2006:180). As 'pure gevoel' verteenwoordig dit ons 'bevind-vanonsself-in-die-wêreld' of soos Strasser dit oorspronklik gestel het, naamlik 'n spesifieke 'felt state of mind, pure being-in-the-mood' (Strasser aangehaal in Stoker 2006:180). Dit verteenwoordig 'n karakteristieke eienskap van menslike bestaan wat uitdrukking gee aan ons 'behoorttot-bestaan'. So stel Stoker (2006):

This feeling of belonging to being is the ontological feeling. Just like a psychological feeling, it is affectively charged but differs from the former in that it indicates a property of our humanness: our connection with our (life) world. It is a basic feeling of the human being. (bl. 181)

Om hierdie rede kan Stoker (2006) dan met oortuiging die affektief-kognitiewe dimensie van menswees verdedig:

Not only emotion but also mood influences our rational thought and our behaviour. The human being is a whole of bios, pathos and logos. Viewing affectivity as layered is an attempt to do justice to the different aspects of our humanness. (bl. 179)

En vanuit sy neurowetenskaplike bevindinge kan LeDoux (1996) reeds vroeër in aansluiting hierby insigtelik stel:

23.Stephan Strasser is Emeritusprofessor in Filosofiese Psigologie en Antropologie van die Universiteit van Nijmegen, Nederland.

24.Sien Stoker (2006:180 e.v.) se meer omvattende uiteensetting hiervan, veral oor die sogenaamde pre-intensionele aard daarvan. Die fonteinbeeld wat Strasser gebruik om die gelaagdheid van affektiwiteit te verduidelik, is besonders insiggewend. 
... [P]eople normally do things all sorts of things for reasons they are not consciously aware of (because the behavior is produced by brain systems that operate unconsciously) and that one of the main jobs of consciousness is to keep our life tied together into a coherent story, a self-concept. (bl. 33)

Om ons biologies bepaalde lewens dan 'tied together' te hou in geïntegreerde lewensstories vanuit singewende religieuse simbole (voor God), word na my oordeel ten diepste bepaal in die lewenskonteks (habitat) waarin ons ons bevind wat na my oordeel baie goed beskrywe word in die besondere woorde van die Franse filosoof Michael Polanyi (1962):

Our believing is conditioned at its source by our belonging. (bl. 322)

Hoe voeg ons hierdie insigte dan alles singewend tesame? Gemoed $^{25}$ (en dus ons ongedifferensieerde gevoel van behoort) en ons emosies vloei daagliks ineen ${ }^{26}$ in ons denke en optredes in ons harte. Gevoel internaliseer en verpersoonlik 'my denke' en 'my optredes'. In metaforiese taal uitgedruk: Die hart voeg ononderbroke saam en integreer (wat LeDoux noem 'to keep our life tied together into a coherent story, a self-concept') wat die rede of menslike kennis uitmekaar haal of dissekteer of fragmenteer (vgl. Stoker 2006:184 e.v.). Dit is wat ek bedoel met die affektief-kognitiewe dimensie van menswees. Dit sou ek wou omskrywe as evolusionêrteologiese herkonseptualisering vanuit ons biologiese herkoms van die beroemde woorde van die Franse teoloogfilosoof Blaise Pascal (1623-1662) in sy Pensées ${ }^{27}$ wat na sy dood in 1670 uitgegee is: 'Die hart het redes waarvan die rede nie eers weet nie.' En verder, 'Dit is die hart wat God ervaar en nie die rede nie. Dit is dan geloof: om God met jou hart te voel' (Pascal [1670] 1954:78). Vervolgens wil ek hierdie insigte ten slotte saamknoop.

\section{Met verlangende harte na geborgenheid in ons habitat voor God}

Affektiwiteit verteenwoordig vanuit ons biologiese bepaaldheid en evolusionêre herkoms 'n lewensbestanddeel

25.Die gemoed as 'ongedifferensieerde massa' soos Stoker daarvan praat kom grootliks ooreen met wat Damasio (vgl. 1999:48) 'backgroundfeelings' noem. Enkele omskrywinge hiervan deur Damasio kan dit bevestig. So stel hy elders dat 'backgroundfeelings' is as 'nonconscious system ... deeply interwoven with the conscious reasoning system' (Damasio 1999:302). En dan verder: 'You may find yourself in a sad or happy state, and yet you may be at loss as to why you are in yourself in a sad or happy state, and yet you may be at loss as to why you are in
that particular state now' (Damasio 1999:302). Die rede hiervoor is duidelik: 'All emotions use the body as theater..., but emotions also effect the mode of operation of numerous brain circuits: the variety of the emotional responses is responsible for profound changes in both the body landscape and the brain landscape. The collection of these changes constitutes the substrate for the neu
eventually become feelings of emotions' (Damasio 1999:51-52).

26.Sien Stoker (2006:182 e.v.) vir 'n meer gedetaileerde bespreking van die interaksie tussen gemoed en emosies. Mooi stel Stoker (2006:182) hierdie verhouding in poetise taal: 'Moods supply the leitmotif of the song, whereas feelings such as emotions are the changing melody.

27.Die oorspronklike titel is Apologie de la religion Chrétienne (Defense of the Christian Religion). Die eerste uitgawe van sy boek wat toe met die titel Pensees in 1670 verskyn het is nie van veel waarde nie aangesien die oorspronklike materiaal baie verander is deur die redakteurs. Alhoewel uitgawes ook in 1776 (Condorat), 1779 (Bossuet), 1785 (Ducreux) en 1835 (de Frantin) verskyn het, is die eerste werklike goeie teks deur Faugère in 1844 uitgegee waarop' $n$ hele aantal tekste kort daarna gevolg het en uiteindelik 'n hele aantal vertalings met die eerste Engelse eBook (http://www.gutenberg.org/ebooks/18269) in 2006. Ek vertaal hier vrylik uit die uitgawe van Pascal's Pensees (1954:78) wat oorspronklik deur William Finlayson uitgawe van Pascal's Pensees (1954:78) wat oorspronklik deur
Trotter vertaal is en deur die uitgewer Dutton gepubliseer is. van ons nie-bewustelike en bewustelike integrering van ons onderskeie lewenstories in spesifieke omgewings (habitats). In hierdie konteks kan die woorde van die Spreukeskrywer (Spr 4:23) ons dus vanuit hierdie perspektief kragtig nuut aanspreek: 'Wees veral versigtig met wat in jou hart omgaan want dit bepaal jou hele lewe.' Op hierdie wyse speel dit 'n vormgewende rol in ons lewenswêrelde waarin ons vanuit ons diepste 'verlange na geborgenheid' singewend uitdrukking en verbeeldingsvol gestalte gee op affektief-kognitiewe wyse aan die kwalitatiewe betekenis en inhoud van 'lewe' - wat dit inderdaad lewenswerd - of nie - maak (vgl. De Sousa 2013:1). Op hierdie wyse verteenwoordig affektiwiteit die beliggaming van die logika van ons oorlewing.

Kortweg samevattend gestel: Ons oorlewe nie omdat ons so sterk of goed aangepas is in ons betrokke habitat nie, maar op grond van ons affektief-kognitiewe sinsgewende en verbeeldingsvolle omgang in en met ons leefwêrelde. ${ }^{28}$ Hierdie singewende omgang sou nader affektief aangedui kon word as mee- of inlewing waaronder ek begrippe insluit soos beleefdheid, goedheid, gasvryheid, deernis, empatie..$^{29}$ Juis hierdie moment sou ek wou toevoeg tot Buitendag se besondere klem op die eko-teologiese verstaan van menswees en die konstituerende belang van die habitat. Op nuwe wyse kom die uitnodiging as uitdaging hier en nou ter sprake om die Engelse idiomatiese uitdrukking 'home is where your heart is' uit te werk in evolusionêre terme as sinvolle medemenslike bestaan voor 'n liefdevolle God van wie ons verwag om ons diep biologies - wat ook veel meer is as net dit - bepaalde verlange na geborgenheid te stil.

\section{Erkenning Mededingende belange}

Die outeur verklaar dat hy geen finansiële of persoonlike verbintenis het met enige party wat hom nadelig kon beïnvloed in die skryf van hierdie artikel nie.

\section{References}

Barber, N., 2004, Kindness in a cruel world: The evolution of altruism, Promotheus Books, New York, NY.

Buitendag, J., 2009, 'Nature as creation from an eco-hermeneutical perspective: From a "natural theology" to a "theology of nature", HTS Teologiese Studies/ Theological Studies 65(1), Art. \#272, 10 pages. DOI:10.4102/hts.v65i1.272. http:// Theological Studies 65(1), Art. \#272,
dx.doi.org/10.4102/hts.v65i1.272

Buitendag, J., 2012, 'Die noodsaaklikheid van habitat in ons definisie van menswees: Op soek na 'n eko-teologiese verstaan van menslike lewe', HTS Teologiese Studies/ Theological Studies 68(1), Art. \#1283, 8 pages. http://dx.doi.org/10.4102/hts. v68i1.1283

Cunningham, C., 2010, Darwin's pious idea, Eerdmans, Grand Rapid, MI.

Damasio, A.R., 1999, The feeling of what happens: Body and emotion in the making of consciousness, Harcourt Brace \& Company, New York, NY.

De Sousa, R., 2013, s.v. 'Emotion', in E.N. Zalta (ed.), The Stanford Encyclopedia of Philosophy (Spring 2014 Edition), viewed no date, from http://plato.stanford.edu/ archives/spr2014/entries/emotion

28.Dit is die meer wat ek aan die begin gestel het (sien 'Inleiding') wat nog kort in my verwysing na Polkinghorne se 'Les ons dors na ' $\mathrm{n}$ dieper vlak van kennis' en Ellis se 'Help ons om uit te kom by die volheid van menswees.' Die 'iets' wat in hierdie goeie omskrywinge van hulle kort, is na my oordeel juis hierdie element van ons affektief-kognitiewe sinsgewende en verbeeldingsvolle omgang in en met ons leefwêrelde.

29.Verskeie publikasies wat spesifiek hierdie vraag vanuit ' $n$ evolusionêre perspektie stel het reeds hieroor verskyn. Om maar enkeles te noem: Nigel Barber (2004) se Kindness in a cruel world: the evolution of altruism; Dacher Keltner (2009) se Born Kindness in a cruel world: the evolution of altruism; Dacher Keltner (2009) se Born
to be good; Frans de Waal (2009) se Age of empathy en David Hamilton (2010) se to be good; Frans de Waal (200
Why kindness is good for you. 
De Waal, F., 2009, Age of empathy, Three Rivers Press, New York, NY.

Dingemanns, G., 2012, Het brein geeft te denken, Free Musketeers, Zoetermeer.

Du Toit, C.W., 2007a, 'Values in the science-religion dialogue: biological roots of human nature and interaction with cultural environment', in Viewed form the shoulders of God: Themes in science and theology, pp. 15-44, RITR, Unisa, Pretoria.

Du Toit, C.W., 2007b, Viewed form the shoulders of God: Themes in science and theology, Research Institute for Theology and Religion, Unisa, Pretoria.

Du Toit, C.W., 2012, 'Immanent transcendence and the nature of life: developments from Schrödinger to Kauffman', ESSSAT Conference Proceedings, Tartu, Estonia, April 24-29, 2012, pp. 47-56.

Ellis, F.R.G., 2006, 'Why the science and religion dialogue matters', in F. Watts \& $\mathrm{K}$. Dutton (eds.), Why the science and religion dialogue matters, pp. 3-26, Templeton Foundation Press, West Conshohocken, PA.

Fuchs, T., 2009, 'Embodied cognitive neuroscience and its consequences for psychiatry', viewed 25 February 2014, from https://www.klinikum.uniheidelberg.de/fileadmin/zpm/psychatrie/fuchs/Embodied.Cogn.Neurosci.pdf

Gregersen, N.H. \& Van Hyssteen J.W. (eds.), 1998, 'Theology and science in a pluralist world: An introduction', in N.H. Gregersen \& J.W Van Huyssteen (eds.) Rethinking theology and science, pp. 1-12, Eerdmans, Grand Rapids, MI.

Hamilton, D., 2010, Why kindness is good for you, Hay House, London.

Hefner, P., 2008, 'Religion-and-Science, the third community', Zygon 43(1), 3-8. http://dx.doi.org/10.1111/j.1467-9744.2008.00893.x

Keltner, D., 2009, Born to be good, W.W. Norton, New York, NY.

LeDoux, J., 1996, The emotional brain: The mysterious underpinnings of emotional life, Simon \& Schuster, New York, NY.
Nürnberger, K., 2013, Informed by science - Involved by Christ: How science can update, enrich and empower the Christian faith, Cluster Publications, Pietermaritzburg.

Pascal, B., [1670] 1954, Pascal's Pensees, introduction by T. Eliot, transl. W. Finlayson Trotter, Dutton, New York, NY.

Polanyi, M., 1962, Personal knowledge: Towards a postcritical philosophy, Chicago University Press, Chicago, IL.

Polkinghorne, J., 2006, 'Does "Science and Religion" matter?' , in F. Watts \& K. Dutton (eds), Why the science and religion dialogue matters, pp. 27-32, Templeton Foundation Press, London.

Polkinghorne, J., \& Welker, M. (eds.), 2000, The end of the world and the ends of God: Science and Theology on Eschatology, Trinity Press, Harrisburg, PA.

Stoker, W., 2006, Is faith rational? , Peters, Leuven.

Van Dyk, P.J., 2013, 'The Bible and evolution: Opinions amongst southern African clergy and theologians from the Reformed church tradition', Verbum et Ecclesia 34(1), Art. \#776, 9 pages. http://dx.doi.org/10.4102/ve.v34i1.776

Van Fraassen, B., 2002, The empirical stance, Yale University Press, New Haven, CT.

Van Huyssteen, J.W.V., 2011, 'Post-Foundationalism and human uniqueness: A reply to Responses', Toronto Journal of Theology 27(1) 73-86. http://dx.doi. org/10.3138/tjt.27.1.73

Veldsman, D.P., 2012, "Life is what? On "giveness" and "sensemaking" within the context of the theology-science dialogue', ESSSAT Conference Proceedings, Tartu, Estonia, April 24-29, 2012, pp. 225-236.

Veldsman, D.P., 2013a, 'The bio-century challenge: life in a holistic context. In conversation with Cornel du Toit', Studia Historiae Ecclesticae 39 supp., 22-38.

Veldsman, D.P. 2014, 'With reasons of the heart before God: On religious experience from an evolutionary-theological perspective', conference paper presented at ESSSAT Conference, Assisi, 30 April - 04 May. 